\title{
Parents and their children's choice of school science subjects and career intentions: a study from Mauritius
}

Jayantee Naugah, Open University, Mauritius; Chairperson, Rajiv Gandhi Science Centre, Mauritius; Email: gasatgb@yahoo.com

Michael J Reiss, UCL Institute of Education, University College London

Email: M.Reiss@ioe.ac.uk

Mike Watts, Brunel University London

Email: Mike.Watts@brunel.ac.uk

\begin{abstract}
There are varied and complex forms of parental influence that shape young people's decisions to study science subjects in school and young people's eventual career path. This study identifies the role of parents in influencing the choice of science subjects in Mauritius among students at the end of the third year of secondary education, the level up to which science is a compulsory subject. There is a low uptake of science subjects by girls beyond the compulsory level and this is a matter of concern in the present knowledge-based society. The study was undertaken with parents whose children were in four purposely selected schools in Mauritius, two mixed-sex and two girls' schools. One hundred and twelve completed questionnaires were obtained from the parents of students who had previously been interviewed and/or had their science lessons observed. Analysis of the data shows that parents on the whole felt that they did not influence their children in the choice of subjects or eventual careers, though they held science in high esteem.
\end{abstract}

Keywords: Parents, science subjects, choice, career.

\section{Introduction: parental influence on subject choice}

This article examines the many, varied and complex forms of parental influence that shape young people's decisions to study, or continue studying, science subjects in school. A large literature has stressed the role of parental influence on young people's subject choice within the school curriculum and therefore subsequent career development, not least that summarised by Archer, DeWitt, Osborne, Dillon, Willis and Wong $(2012,2013,2014)$ for whom engagement with school science is primarily shaped by socio-cultural factors: home, family, social status, peers, schools. Their ASPIRES study surveyed the development of young people over the age period 10-14, exploring the influences on their aspiration towards a sciencerelated career. The study combined online surveys of over 9,000 students and repeat 
interviews with a selected sub-sample of students and their parents. Survey and interview data were collected at three time points: age 10/11 (Year 6), the second year of secondary school (age 12/13, Year 8 ) and the third year of secondary school (age 13/14, Year 9). Their analysis indicates that aspirations are:

not simply individual cognitions residing within children's heads, unaffected by their social contexts. Rather, children's aspirations and views of science careers are formed within families, and these families play an important, albeit complex, role in shaping the boundaries and nature of what children can conceive of as possible and desirable and the likelihood of their being able to achieve these aspirations. (Archer et al., 2014, p. 902)

Archer et al. strongly suggest that, using the language of Bourdieu (1977), the interplay of family capital and habitus provides powerful structuring socio-cultural factors and 'Habermasian capital' that strongly influences how children formulate their aspirations and choices.

It may be the case that some parents are disinterested in their children's subsequent careers, though the vast majority across a range of surveys seem at to be generally supportive of their offspring in this regard. Seen from the 'receiving' end, Whiston and Keller (2004) note numerous studies that report young people's perceptions of parental influence on their career choices: about $21 \%$ claim that their career choices are made collaboratively with parents, and about $2 \%$ state that their parents are the main drivers behind their actual decisions. In a recent survey, one of the world's leading design, engineering and project management consultancies reported the responses of 300 women engineers (Atkins, 2013). While $91 \%$ had at least one inspirational teacher, $68 \%$ also said that their school careers advice had been weak and, importantly, the majority $(73 \%)$ said that the idea to be an engineer was largely their own ( $p$. 17). Ninety four per cent of respondents said that their families were solid in providing almost unstinting support for their career choice (the news being a complete surprise to some $11 \%$ ), although this was largely of the 'we'll support you in whatever you want to do, darling' kind and not necessarily directed towards a science career. These women engineers frequently characterised their younger selves as being unusually interested in problem solving, that they had an early over-riding interest in 'fixing things', an interest (practical and academic) that 'naturally' pointed towards engineering.

Stambler (1998) suggests that parents are clearly influential in young people's career choice, and Ferreira et al. (2006) go beyond 'influential', suggesting that parents are one of the key influences that bear on the vocational behaviour of adolescents. Further, Biggart et al. (2004), 
in an analysis of the Scottish School Leavers Survey (SSLS) data, reported that parents are the most commonly reported 'catalyst' for initiating the choice process. There are instances, too, where parental influence can 'catalyse' in an adverse way, moving the young person towards or away- from - science as an act of rebellion (Salehjee \& Watts, 2015). In their work, Archer et al. (2012) also allow for the possibility of children 'going against the grain' (Reay, Crozier \& Clayton, 2010) of formative social and familial expectations. This was seen to work both ways, with some young people resisting a strong science 'steer' from home and others proactively choosing science despite little awareness or science resources at home.

So, from indifference to guidance, influence to catalyst, research demonstrates that parents can have a broad reach. However, while work into intended career choice has demonstrated the general influence of parents, existing research says little about the shape, and the avenues, through which parents influence their children in such matters. According to Baranowski et al. (2002), parents can influence their children's school-choice behaviours through a variety of mechanisms, three of which are: (i) direct parent-child communication about possible subject choice and careers; (ii) both silent and explicit encouragement around particular choices, and (iii) parental behaviour modelling. To date, most of the research pertaining to young people's subject and career choice has focused on the last of these, the modelling hypothesis. This is often based on Bandura's (1977) social learning theory, a set of arguments that suggests a connection between parental occupation and child choices. Bengtsson (1983) sampled 98 female university students and showed that a greater proportion of the women studying natural sciences than those studying humanities had fathers who had studied natural sciences and worked in the field.

It is difficult to isolate key factors that would provide a full and clear picture. According to some expectancy-value theories (for example, Eccles-Parsons et al., 1983; Feather, 1982; Wigfield \& Eccles, 1992), an individual's values for particular goals and tasks can help explain why he or she chooses one activity over another. However, many of these theories do not systematically address other important motivational questions: What actually makes the individual want to engage in something? And, equally important: What makes the individual not want to engage? Moreover, it is not fully clear why choices are made along gendered lines. Young men are still likely to make technical choices while young women choose nursing and the humanities so that, in the UK for example, research undertaken by the Science Council indicates that of the approximately $5.8 \mathrm{~m}$ people employed in science-based roles (around $20 \%$ of the UK workforce), only some $30 \%$ are women (Science Council, 2014). 


\section{Science influences}

The science education literature offers a range of mediating explanations as to why students do or do not choose science once it becomes option, sometimes directed at all young people, sometimes at one gender or the other:

(i) The intrinsic attraction and perceived relevance of the topics within school science In recent years, many studies have been published which present a gloomy picture with respect to the uptake of science, especially at secondary school level. A key claim is that science education - particularly in physics and chemistry - remains unpopular among students (Hofstein, Eilks \& Bybee, 2011; Holbrook, 2008; Osborne \& Dillon, 2008). Students are simply not interested in science learning and/or not motivated by science subjects (Jenkins, 2005; Osborne, Simon \& Collins, 2003). One frequently cited reason is that learners perceive science and science education as both difficult, and as 'irrelevant', both for themselves and for the society in which they live and operate (Dillon, 2009; Gilbert, 2006; Holbrook, 2008). Science teachers have worked to make education 'more relevant' in order to better interest and motivate their students (Holbrook, 2003, 2005; Newton, 1988a, 1988b), however, it remains unclear that this has had much effect.

Wellcome Trust (2010) has also shown that students' disenchantment with secondary science can arise from their failed expectations when transferring from primary to secondary education, rather than the actual 'science' itself. Many pupils had looked forward to doing some 'proper science' when reaching secondary school (Rose, 2003) and were very disappointed with what they then received.

(ii) Student identity and self-perceptions in relation to doing science Findings from the Relevance of Science Education (ROSE) project suggest that the higher the level of development in a country, the lower is the level of interest expressed by students towards science and technology (Sjoberg \& Schreiner, 2005). This might reflect postmaterialistic values of young women in the developed countries in contrast to the developing ones that view science as important for development and improving the quality of life. Schreiner (2006) interpreted the low interest of girls and boys in developed countries in science as a sign of late-modern identity, with girls generally tending to accentuate their femaleness and femininity (Baram-Tsabari et al., 2009).

(iii) Peer and parental pressure on school direction and achievement 
Parental involvement in education is clearly important in facilitating positive development in young people. Numerous studies have identified parental involvement as an important way to promote academic success (Epstein \& Sanders, 2002; Hill \& Taylor, 2004; Jeynes, 2009; Seginer, 2006). An early study by Breakwell and Beardsell (1992) surveyed almost 400 UK pupils aged 11-14. Boys were seen to have more positive attitudes to science and greater levels of participation in scientific extra-curricular activities, and these positive attitudes were strongly positively related to having a father and mother who supported science and to having scientific peers. Having a father who supported science, having parents who engaged in activities jointly with their children and having scientific peers all predicted greater involvement in scientific extra-curricular activities. McNeal $(1999,2001)$ studied the relationship between parental involvement and science achievement and concluded that parent-child discussions based on science education had a significant influence on improving achievement in science-related subjects. Smith and Hausafus (1998) highlighted that, irrespective of ethnicity, students worked better when their parents took them to science museums and fairs, which helped the students to understand the importance and relevance of science education in their lives. The top three student reasons for an interest in STEM reported by Christensen, Knezek and Tyler-Wood (2014) were: (i) a supportive parent/family member (26\%), (ii) a high quality/motivating teacher (17\%) and (iii) self-motivation/naturally inclined (14\%). Another frequently mentioned influence was science fairs/competitions (6\%). Fouad and Bynner (2008) concluded from their three-year study that it is the self-confidence instilled by parents and teachers that is important for girls learning mathematics and science, rather than their initial interest (Rose \& Smith, 2008).

\section{(iv) Teacher role-modelling and influence on subject choices}

In the ROSE Project (Sjoberg \& Schreiner, 2005) science lessons were all too often identified by students as being boring. Beauchamp and Parkinson (2008) indicated that less-thanenthusiastic students rate science lessons as boring because they are poorly taught by teachers who demotivate students. 'Good' teachers make science lessons active and interesting, which motivates the students towards school science learning, since teachers have an active role in shaping pupils' conceptual development towards a specific content by scaffolding their learning (Kellner \& Share, 2007): 'Teaching science is about transforming relevant subject matter content into a form that is comprehensible to pupils' (p. 843).

Taylor (2009) sees the problem as a lack of physics and chemistry specialist teachers as part of a cycle of decline: fewer students choosing pre-university sciences, leading to fewer university 
graduates, and even fewer chemistry and physics graduates who are choosing teaching as a career. As a result, The UK is 'still producing far too few scientists' (p. 71). The UK government's (Her Majesty's Treasury, 2004) ten-year investment framework for science and innovation proposed great emphasis on teaching and learning of STEM subjects and, for this reason, a key element was introducing more teacher training in sciences to increase the supply of qualified science teachers as role models. In response to this initiative, in 2006 the National Foundation for Educational Research (NFER) (Moor et al., 2006) surveyed the deployment of science teachers and supporting staff. Research was undertaken in $25 \%$ of the maintained secondary schools in England and revealed a worrying shortage of science specialist teachers. It showed, too, a significant imbalance in science teacher qualifications: '44\% of science teachers held specialism in biology in contrast to one-quarter with a specialism in chemistry and one-fifth with a specialism in physics' (Moor et al., 2006, p. iii). It was also noted that schools that teach only 11-16 year olds (as opposed to 11-18 year olds) especially lack physics specialist teachers. This prompted the UK's House of Commons Science and Technology Committee $(2010 ; 2011)$ to show concern and point to the negative impact on the quality of teaching. The Committee concluded that a lack of specialist chemistry and physics teachers in the UK creates a considerable risk for the production of 'highly skilled scientists and a scientifically literate workforce in the future' (2010, p. 155).

\section{(v) Out-of-school hobbies, interests, pastimes and leisure pursuits}

One of the reasons for negative attitude of students towards science is 'the widely held perception of science being difficult and not relevant to the lives of most people' (Ramsden, 1998, p. 125). Braund and Reiss (2004) have reported that students view the science curriculum as irrelevant to life outside the classroom. The Office for Standards in Education, Children's Services and Skills (Ofsted) (2008) reported that learning outside the classroom helps to make subject interesting and improves understanding of the topic. Learning outside 'contributes significantly to pupils' personal, social and emotional development' and demonstrates positive outcomes in underachieving students (Ofsted, 2008, p. 7). In comparison to traditional teaching styles, an environmentally-focused science curriculum increases achievement levels in students (State Education and Environment Roundtable: SEER, 2000): 'field work provides a lifetime's inspiration' (Tilling, Lock \& Slingsby, 2006, p. 21).

\section{(vi) Projected career path and lifestyle choices}

The notion of scientific literacy for all learners has been widely proposed and this concept deals with a principal objective of science education, namely 'to attain society's aspirations 
and advance individual development within the context of science and technology' (Bybee, 1997, p. 69). The importance of scientific literacy is emphasised by Millar and Osborne (1998) who argue that the science curriculum from 5-16 should be seen primarily as a course to enhance scientific literacy' (p. 9). The National Research Council reported (1996) an emerging need for scientific literacy in the work place and employers who are scientifically skilled, that is with the ability 'to learn, reason, think creatively, make decisions, and solve problems' (p. 1).

It has also reported that countries are encouraging and investing heavily to produce scientifically literate work forces to progress in the global market. Yet, 'Despite the rhetoric of scientific literacy for all students, science in schools remains virtually unchanged; students are confronted with basic facts and theories' (Roth \& Barton, 2004, p. 5). Moreover, according to Duit and Treagust (2003), findings from many studies over the past three decades show that students do not have sound knowledge of scientific concepts and skills, although they 'hold deeply rooted conceptions and ideas that are not in harmony with science views or are even in stark contrast to them' (p. 671). The present economic needs and advances in how we access and use knowledge are changing societies into knowledge-based societies. Knowledge-based societies are those 'in which people see knowledge in economic terms, as the primary source of all future economic growth' (Bennett et al., 2006, p. 25).

\section{The Mauritian context}

The Republic of Mauritius includes Mauritius, the islands of Rodrigues and Agalega and small islands called the Cargados group; it is situated about $800 \mathrm{~km}$ east of Madagascar. Since independence in 1968 , a considerable number of changes have taken place in the education system with concomitant input of financial and other resources and infrastructural development. Primary education has been compulsory since January 1992 and secondary education since January 2003. Mauritius places great importance on scientific and technological literacy that, it is hoped, will enable its citizens to contribute to human and national development. It is a vision which is linked both to the relevance of science in the everyday life of its citizens and to the creation of a pool of future scientists. However, the Master Plan of Education (1991) and the White Paper in Science (1992) sounded the alarm regarding the low number of students (25\%) who take up science after the compulsory level (Form III; age 14). The majority of students chose accounts or economics. Of the $25 \%$ who opted for science, the number of girls taking science was much lower than boys. Various initiatives and activities were introduced, for example a science action plan, exhibitions and competitions. These led to an increase in the number of pupils taking science up to around 
$40 \%$ of which $60 \%$ are boys and $40 \%$ are girls (Digest of Education Statistics, Ministry of Finance and Economic Development, 2013).

\section{Research question, methods and sample}

Through the use of a parental questionnaire our aim was to find an answer to the research question which was: 'Do parents think they influence the choice of science subjects in Mauritius and if so how?'. After piloting the questionnaire in a different class from the ones under study and after making a few modifications from the feedback received from the pilot, we administered them to the parents of the students in Form III (aged 14) in the four case study schools. Questions 5, 6 and 8 in the questionnaire were about parents' perceptions of science and their influence on the choice of subjects their children would take after the compulsory level and on their subsequent career path.

\section{Ethical considerations}

We were careful in asking questions that the participants in the study would not find too sensitive or invasive of their privacy. The questionnaire asked some general details about the participant and some open-ended questions which would not require a great deal of time to complete; we were careful about how we addressed the parents and got their support to respond to the questionnaire. We tried to include some internal validity checks by asking some open-ended questions in another form, for example in questions 4 to 8 (Appendix 1), by asking respondents to give reasons for their answer to a closed question.

In a fairly short time, we managed to obtain a substantial amount of information from the parents with a high response rate (83\%; 112 returns from 135 sent out). There was minimum researcher bias, as we had no personal contact with the parents. On the other hand, there might have been instances where the parents needed some clarifications or help with some of the questions. However, this was not evident from the responses; there were a few cases where some words were written in French and these were checked for the meaning they were conveying and the answers did not show that there was any misunderstanding of the questions asked.

\section{The questionnaire}

We showed a copy of the questionnaire to the rector/principal of each of the four selected schools so as to obtain their cooperation; we thought that using the teachers and the rectors as personal contacts would increase the response rate (Wellington, 2000). We talked to the 
pupils to make it more likely that their parents would complete the questionnaires and we politely explained in the letter addressed to the parents the aim of the research; we also explained to the pupils what the questionnaire was about so that they in turn could explain to their parents the purpose of the survey should they have any doubt about some of the items.

We ensured that the questions were straightforward and formulated in simple English. Clear instructions were given on how to answer them. Careful thought was given to the length and order of the questions; awkward, embarrassing and leading questions were avoided. The layout of the questionnaire included space between the open-ended questions so that respondents could write their comments (Appendix 1). Questions 1 to 4 were straightforward and aimed at getting the personal background of the respondent and were closed. Where there was a YES/NO answer, respondents had to provide reasons for their answer. Similarly, questions 5, 6 and 8 each had a YES/NO answer section but there was an open-ended subsection that allowed for free responses. The open-ended questions took more time to analyse as the responses were of a qualitative nature involving opinions, feelings and value judgments and we restricted them to a few in numbers. Most of the questions were answered; in only a few cases did the respondents omit to answer. This was particularly the case for question 4a that referred to the level up to which respondents had studied science. We found that this omission was not surprising because these respondents' education in science did not go up to School Certificate level. The words 'respondents' and 'parents' are used interchangeably.

\section{Results}

For data analysis purposes, the parents in the sample were classified, depending on their response to question 2 , into five categories based on the type of work they did:

1: Manual work (e.g. labourer)

2: Semi-skilled work (e.g. builder, mechanic)

3: Office work (e.g. clerk, secretary, administrative officer)

4: Professional (e.g. engineer, accountant, surveyor, lecturer)

5: Not specified.

The raw data for the samples in the four schools were processed and analysed using Excel software. Identifiers were given for each questionnaire; for example $A 1, A 2$, for school $A, B 1$, B2, for school B, C1, C2 for school C and D1, D2 for school D samples. The processing of the 
closed questions was straightforward. The free response questions were read and appropriate coding frames were designed (Oppenheim, 1999, p. 267).

The data for the four schools were initially combined to obtain an overall picture of the responses made by the parents. The data for each school are then presented separately for closed answers and then selected excerpts from the open questions are presented and interpreted.

\section{Combined data from the four schools}

Table 1 shows the aggregated data for the four schools. Question 1 refers to the sex of the respondent who was filling in the questionnaire. However, it is to be noted that both parents were expected to discuss the questionnaire and complete the questionnaire jointly. In Table 1, the column 'Sex of respondent' indicates that slightly over half of the questionnaires were completed by the mothers ( 59 mothers against 53 fathers).

\begin{tabular}{|c|c|c|c|c|}
\hline \multirow{2}{*}{ Category } & \multirow{2}{*}{ Mother } & \multirow{2}{*}{ Father } & \multicolumn{2}{|c|}{ Sex of Respondent } \\
\cline { 4 - 6 } & & & Male & Female \\
\hline Manual Work & 56 & 28 & 13 & 28 \\
\hline Semi-skilled & 22 & 38 & 19 & 15 \\
\hline Office Work & 11 & 15 & 10 & 6 \\
\hline Professional & 5 & 10 & 4 & 5 \\
\hline Not Specify & 18 & 21 & 7 & 5 \\
\hline & 112 & 112 & 53 & 59 \\
\hline & & & \multicolumn{3}{|c|}{$\mathbf{1 1 2}$} \\
\hline
\end{tabular}

Table 1: Combined data from all four schools on parental occupation and who completed the questionnaire.

A comparison of the occupation data in Table 1 reveals that 56 of the 112 mothers were involved in manual work whereas only 28 of the 112 fathers were in that occupational category; 22 mothers and 38 fathers were in semi-skilled occupations. A smaller number of parents ( 16 mothers and 26 fathers) were in office or professional work and 18 mothers and 21 fathers did not specify the type of occupation they were in.

\section{Respondents' science education}

Figure 1 shows the science education background of the respondents in the four schools. Most of the parents (71 out of 112) in the various social categories had a background of science education at secondary level. However, there were a fair number of parents who had not 
studied science at this level and this was more evident among those who were in the manual and semi-skilled categories. These are likely mainly to have been parents who did not have the opportunity to study beyond primary level. However, compulsory science education at secondary level up to Form III was only introduced in Mauritius in the early 1980s and it is likely that many of those parents in the office work and professional categories who did not study science at secondary level undertook their secondary education at a time when their schools did not teach science.

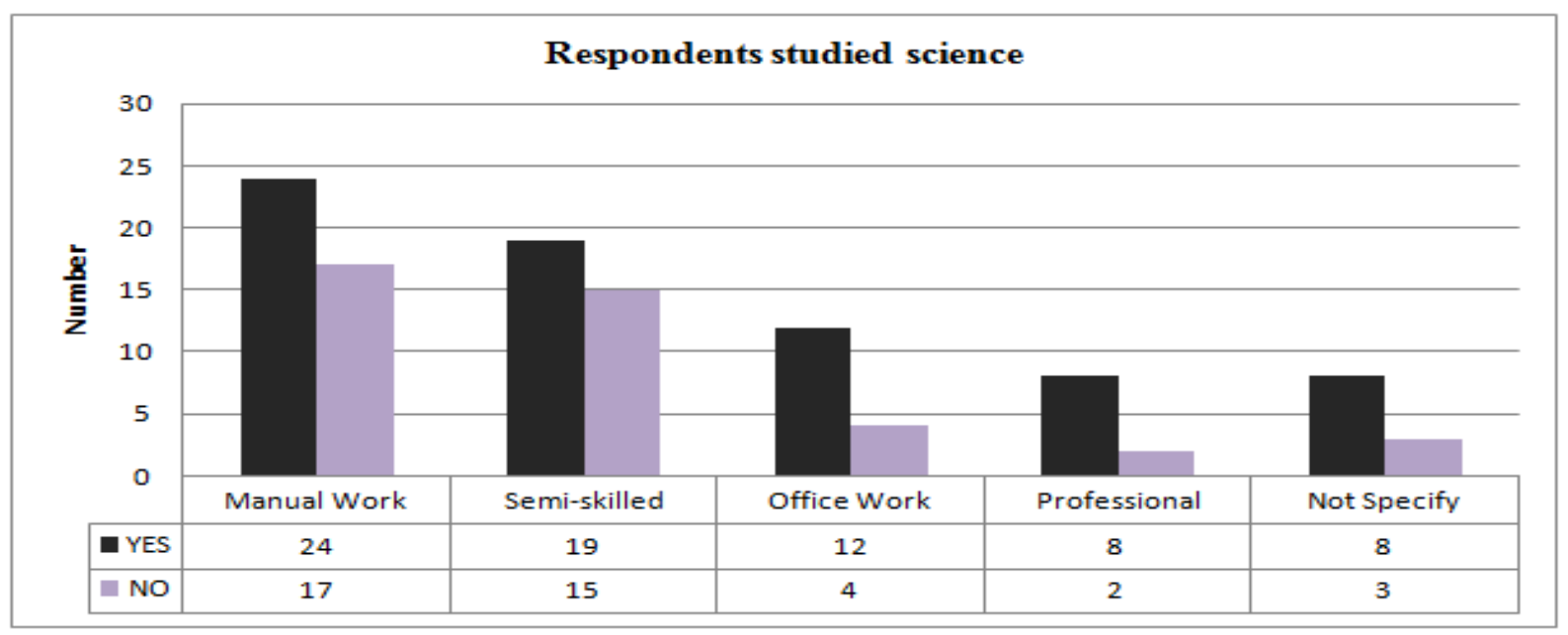

Figure 1: Combined data from all four schools on the relationship between parental occupation and the study of science at secondary school.

\section{Parental valuation of science}

Figure 2 shows that the study of science is highly valued by the great majority of respondents irrespective of their social status. For example, 106 out of 112 parents attached a great importance to the study of science. 


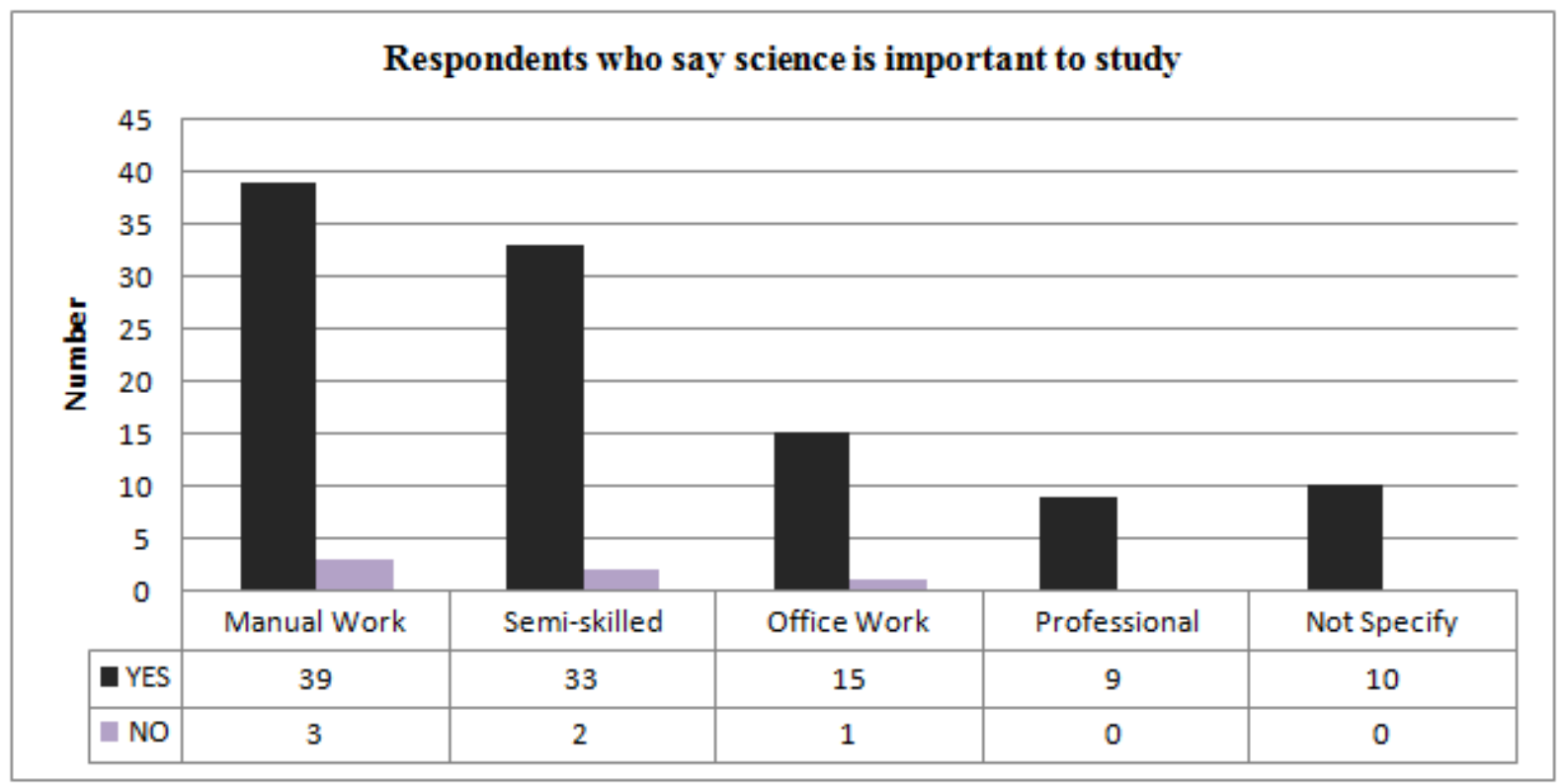

Figure 2: Parents who say that science is important to study across all four schools.

\section{Influence of parents on the choice of subjects}

Figure 3 illustrates whether parents say they have an influence on the choice of subjects at Form III level.

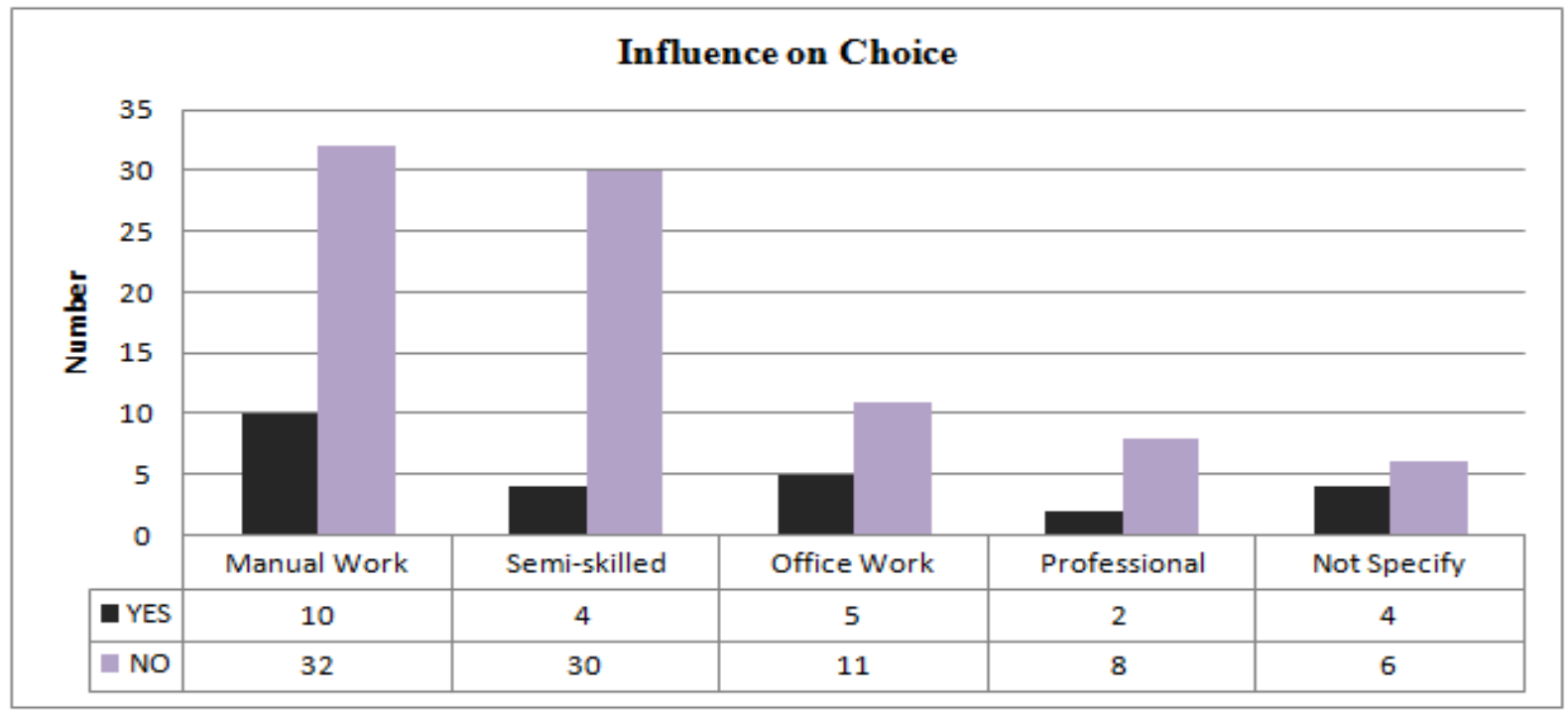

Figure 3: Parents' views about their influence on their children's choice of subjects across all schools.

The majority of parents in each occupational category listed in the study, perhaps especially among the semi-skilled workers, claimed that they did not influence their children on their choice of subjects at age 14 (Figure 3). However, some parents stated that to a certain extent they do exert an influence in their children's choice of subjects. A fair number of parents said they gave some explicit encouragement around particular subject and career choices. Excerpts 
will now be presented in the school-specific results to illustrate the views of the parents on these aspects.

\section{School A}

Table 2 summarises the background information on the parents in School A, the importance they attach to science and their stated influence on their children's choice of subjects.

\begin{tabular}{|c|c|c|c|c|c|c|c|c|c|c|}
\hline \multirow{2}{*}{ Category } & \multirow{2}{*}{ Mother } & \multirow{2}{*}{ Father } & \multicolumn{2}{|c|}{ Sex of Respondent } & \multicolumn{2}{|c|}{ Study Science } & \multicolumn{2}{|c|}{ Science important to study } & \multicolumn{2}{|c|}{ Influence on Choice } \\
\hline & & & M & $\mathbf{F}$ & YES & No & YES & No & YES & No \\
\hline Manual Work & 22 & 6 & 3 & 8 & 5 & 6 & 10 & 1 & 3 & 8 \\
\hline Semi-skilled & 5 & 15 & 9 & 3 & 5 & 6 & 11 & 1 & 1 & 10 \\
\hline Office Work & 1 & 3 & 3 & 0 & 2 & 1 & 3 & 0 & 2 & 1 \\
\hline Professional & 0 & 4 & 2 & 0 & 1 & 2 & 2 & 0 & 0 & 3 \\
\hline \multirow[t]{3}{*}{ Not Specify } & 3 & 3 & 2 & 1 & 2 & 1 & 3 & 0 & 1 & 2 \\
\hline & 31 & 31 & 19 & 12 & 15 & 16 & 29 & 2 & 7 & 24 \\
\hline & & & \multicolumn{2}{|c|}{31} & & & & & & \\
\hline
\end{tabular}

Table 2: Background information on the parents in School A, the importance they attach to science and their stated influence on their children's choice of subjects.

School A is a single-sex girls' school in a semi-urban region. It is evident that a majority of the mothers (22 out of 31 ) were employed in manual work whilst 15 out of 31 of the fathers were in semi-skilled occupations and a limited number were office workers or professionals.

Parents'science education. The data from Table 2 show that slightly over half of the parents involved in manual and semi-skilled occupations had not themselves studied science at secondary school.

The importance of studying science. In response to the question Do you think the study of science is important?, it was found that the great majority of respondents (29 out of 31) acknowledged the importance of science. As indicated in the quotations below, parent A1 expressed the opinion that the study of science is important for progress and to make life comfortable whilst parents $A 2$ and $A 3$ were of the view that science is important as it helps us to understand life and make discoveries, while parent A4 pointed out the career opportunities offered by the study of science: 
Parent A1 (semi-skilled): Science is making the world and civilisation progress and it has helped a lot in making people achieve comfort in everyday life.

Parent A2 (manual work): Science is based on facts and a basic knowledge in science is necessary for everyday life. We get to know life and understand it better.

Parent A3 (professional): Because it enables a child to become a doctor or engineer and it is a very interesting subject.

Parent A4 (professional): It helps us to explore and discover the world in which we live and make scientific discoveries.

In response to the question: Would you like your daughter/son to study science after Form III? Give reasons for your answer, parent A1 recognises the wide range of opportunities offered by the study of science whereas parent $\mathrm{A} 2$ is more concerned with the financial cost that studying a science subject at higher level entails:

Parent A1: Yes. It will be first of all because it's quite an interesting field and also with wide range of job opportunities. As a parent, I will be proud to see my daughter studying science and later working in a science field.

Parent A2: Firstly, my daughter has a preference for accounts and economics. Besides, it costs quite a lot of money to pursue studies in science subjects in higher classes and more at tertiary level.

In response to the question: What would you like your daughter/son to do as a career?, parent A1 would like his daughter to embark on a scientific career whilst parent A2 would prefer his daughter to follow a career in the financial sector:

Parent A1: Veterinary surgeon.

Parent A2: Would like daughter to be Chartered Financial Analyst...There are few CFAs in Mauritius and it is a highly demanded job. 
Parents' influence on choice of subjects.

It is noteworthy (Table 2) that only a minority of parents (7 out of 31 ) from the different social categories said they have an influence on the choice of subjects.

In response to the question: Do you influence your daughter/son in the choice of subjects? If yes, how? If no, who influences her/him?, parents $\mathrm{A} 1$ and $\mathrm{A} 2$ expressed the following views:

Parent A1: No I do not influence her; it's her choice.

Parent A2: I advise her about the pros and cons of different fields of study and the long-term consequences.

The above excerpts show that parent $\mathrm{A} 1$ claims he does not influence his daughter on the choice of subjects but earlier he stated that he would be proud to see his daughter choosing science subjects. On the other hand, parent A2 expressed the view that he advises his daughter on the choice of subjects.

\section{School B}

Table 3 and the extracts given below illustrate the views held by the parents of the pupils in School B.

\begin{tabular}{|c|c|c|c|c|c|c|c|c|c|c|}
\hline \multirow{2}{*}{ Category } & \multirow{2}{*}{ Mother } & \multirow{2}{*}{ Father } & \multicolumn{2}{|c|}{ Sex of Respondent } & \multicolumn{2}{|c|}{ Study Science } & \multicolumn{2}{|c|}{ Science important to study } & \multicolumn{2}{|c|}{ Influence on Choice } \\
\hline & & & M & F & YES & No & YES & No & YES & No \\
\hline Manual Work & 0 & 0 & 0 & 0 & 0 & 0 & 0 & 0 & 0 & 0 \\
\hline Semi-skilled & 7 & 8 & 3 & 4 & 5 & 2 & 7 & 0 & 1 & 6 \\
\hline Office Work & 4 & 5 & 3 & 3 & 4 & 2 & 5 & 1 & 2 & 4 \\
\hline Professional & 5 & 5 & 2 & 4 & 6 & 0 & 6 & 0 & 2 & 4 \\
\hline \multirow[t]{3}{*}{ Not Specify } & 6 & 4 & 1 & 2 & 3 & 0 & 3 & 0 & 1 & 2 \\
\hline & 22 & 22 & 9 & 13 & 18 & 4 & 21 & 1 & 6 & 16 \\
\hline & & & \multicolumn{2}{|c|}{22} & & & & & & \\
\hline
\end{tabular}

Table 3: Background information on the parents in School B, the importance they attach to science and their stated influence on their children's choice of subjects. 
School B is a mixed-sex school situated in an urban area. Strikingly, the sample did not have any parents involved in manual work; they were all in semi-skilled occupations, in office work or were professionals.

Respondents' science education. The data from Table 3 show that the large majority (18 out of 22) of the parents in School B have studied science at secondary level.

The importance of studying science. As indicated in Table 3, almost all of the parents have positive attitudes towards the study of science. In responses to the question: Do you think the study of science is important?, parents B1, B2 and B3tended to hold science in high esteem. Parent B1, who is a housewife whose spouse is a manual worker and has a son studying in school B, said:

It helps us to understand our surroundings. It helps in the development of general knowledge.

Parent B2, who has a son studying in school B, indicated that he did not study science at secondary level:

Because I wasn't interested in it.

However, he values the importance of science, stating that science equips people with knowledge:

Because in science, we get to know a lot of things, so people will not be able to fool us.

Parent B2, who is female and a Muslim, occupation not specified, has a daughter studying in school B and has not studied science. She recognises the need for scientific and technological literacy:

Subject was not yet introduced in school. Science is important because now everything around us is science, new technology and to know how it works. 
In response to the question: Would you like your daughter/son to study science after Form III? Give reasons for your answer, parents B1, B2 and B3 expressed positive views on this issue.

Parent B1 would like her son to study science after Form III, saying:

He is very good in science. He seems interested in this subject.

Similarly, Parent B2 stated:

Yes. It is important and to increase her knowledge.

Parent B3 would like his son to study science after Form III and his response to this question was:

Yes. It is very advantageous.

In response to the question: What would you like your daughter/son to do as a career?, parents B1 and B2 were in favour of a career in science and technology whereas parent B3 was for a career in the financial sector as it is lucrative in terms of earning potential:

Parent B1: Computer engineer. It is a very interesting job as we are in the computer age.

Parent B2: Doctor or teacher for science subject.

Parent B3: I want him to work in big enterprises, such as banks. Because he will get a good salary and obtain loan facilities.

Parents' influence on choice of subjects. In response to the question: Do you influence your daughter/son in the choice of subjects? If yes, how? If no, who influences her/him?, as in the case of school A, the parents on the whole stated that they do not influence their children on the choice of subjects: 
Parent B1: No. He chooses his subjects on his own.

However, parent B3 would influence his son on his choice of subject:

By explaining him, how important these subjects are and its importance in his future life.

Similarly, parent B2 would influence her daughter on the choice of subject:

As I have some ideas and as I know how she works in the subjects, I help her choose her subjects.

The views of parent B1 on the choice of subjects are typical of a minority of parents in school B.

There are some cases, for example in the case of parent B4, where a relative such as a brother, sister, aunt or uncle is said to have an influence on the choice of subjects and career. Parent B5 stated that her daughter was influenced by her father when he fell ill and she was eager to help those who were poor and suffering.

\section{School C}

Table 4 presents the data for school C. School C is a single-sex girls' school located in an urban area. The respondents are mainly females.

\begin{tabular}{|c|c|c|c|c|c|c|c|c|c|c|}
\hline \multirow{2}{*}{ Category } & \multirow{2}{*}{ Mother } & \multirow{2}{*}{ Father } & \multicolumn{2}{|c|}{ Sex of Respondent } & \multicolumn{2}{|c|}{ Study Science } & \multicolumn{2}{|c|}{ Science important to study } & \multicolumn{2}{|c|}{ Influence on Choice } \\
\hline & & & M & $\mathbf{F}$ & YES & No & YES & No & YES & No \\
\hline Manual Work & 11 & 5 & 0 & 8 & 5 & 4 & 8 & 1 & 2 & 7 \\
\hline Semi-skilled & 4 & 9 & 3 & 3 & 4 & 3 & 6 & 1 & 0 & 7 \\
\hline Office Work & 6 & 7 & 4 & 3 & 6 & 1 & 7 & 0 & 1 & 6 \\
\hline Professional & 0 & 1 & 0 & 1 & 1 & 0 & 1 & 0 & 0 & 1 \\
\hline \multirow[t]{3}{*}{ Not Specify } & 6 & 5 & 3 & 2 & 2 & 1 & 3 & 0 & 1 & 2 \\
\hline & 27 & 27 & 10 & 17 & 18 & 9 & 25 & 2 & 4 & 23 \\
\hline & & & \multicolumn{2}{|c|}{27} & & & & & & \\
\hline
\end{tabular}

Table 4: Background information on the parents in School C, the importance they attach to science and their stated influence on their children's choice of subjects. 
Respondents' science education.

Table 4 shows that the majority of the parents have a science background up to secondary level. Those parents who said they did not study science at secondary level were mostly from manual and semi-skilled occupations.

The importance of studying science. Science appears to be highly valued by the parents in school C. Only two parents had contrary views. In response to the question: Do you think the study of science is important?, parent $\mathrm{C} 1$, who is a female professional of Chinese origin and has a secondary level background in science, replied:

Study of science is important. There are many prospects in this field.

Parent C2 who is a male of Hindu origin, has a science background and is a professional, wrote:

Study of science is important. Science is the basis behind everything in life so a good understanding is important.

Parent C3 is of a similar view too:

Science languages are needed everywhere. Almost everything around us is somehow related to science.

In response to the question: Would you like your daughter/son to study science after Form III? Give reasons for your answer, many parents stated that they would like their daughters to study science after Form III:

Parent C1: Yes. I would have liked her to choose science subjects but unfortunately she has opted to study economics and accounts. 
Parent C2: By studying science she would have a broad choice of careers later ranging from being a teacher, engineer or other professional.

Parent C3: She intends to pursue further studies in a scientific field.

In response to the question: What would you like your daughter/son to do as a career?, Parents C1 and C2 seem to have high career aspirations for their daughters. Both parents would like their daughters to choose a career in the health sector. Whilst parent C1's statement tends to indicate that as a parent she may have a personal reason for that choice, parent $\mathrm{C} 2$ recognises that it is his daughter's ambition to become a doctor.

Parent C1: Dietician. Because youngsters eat too much junk food.

Parent C2: Doctor, medical practitioner. This is her ambition.

Parent C3: Paramedical field. Self-employed in the future.

Parents' influence on choice of subjects. Clearly, the great majority of parents (23 out of 27 respondents) maintained that they do not influence their children on their choice of subjects. In response to the question: Do you influence your daughter/son in the choice of subjects? If yes, how? If no, who influences her/him?, the following excerpts show that the parents differed in their views:

Parent C1: Yes. By explaining to her the importance of certain subjects in the understanding of the world. What decision she takes by the end of the day is her choice.

Parent C2: Yes. We guide her so that her choice reflects the career she would choose.

Parent C3: Yes. I direct her, especially in her future career.

Parent C1's statement reflects that she has no influence on the career choice of her daughter, though she influences her on the choice of subjects: 
Parent C1: It is important that she chooses a career she feels comfortable \& happy with.

Parent C2: Doctor (medical practitioner). This is her ambition.

Parent C2 and C3 reported that their role is more like a guide. On the other hand, parent C4 would not like her daughter to study science:

Parent C4: ... there is few scope for scientific jobs in the Mauritian context as we do not give much importance to research and development.

\section{School D}

School $\mathrm{D}$ is located in a rural area and most of the parents are involved in manual work; there are only a minority in semi-skilled occupation. The results from the parents' sample are presented in Table 5.

\begin{tabular}{|c|c|c|c|c|c|c|c|c|c|c|}
\hline \multirow{2}{*}{ Category } & \multirow{2}{*}{ Mother } & \multirow{2}{*}{ Father } & \multicolumn{2}{|c|}{ Sex of Respondent } & \multicolumn{2}{|c|}{ Study Science } & \multicolumn{2}{|c|}{ Science important to study } & \multicolumn{2}{|c|}{ Influence on Choice } \\
\hline & & & M & F & YES & No & YES & No & YES & No \\
\hline Manual Work & 23 & 17 & 10 & 12 & 14 & 7 & 21 & 1 & 5 & 17 \\
\hline Semi-skilled & 6 & 6 & 4 & 5 & 5 & 4 & 9 & 0 & 2 & 7 \\
\hline Office Work & 0 & 0 & 0 & 0 & 0 & 0 & 0 & 0 & 0 & 0 \\
\hline Professional & 0 & 0 & 0 & 0 & 0 & 0 & 0 & 0 & 0 & 0 \\
\hline \multirow[t]{3}{*}{ Not Specify } & 3 & 9 & 1 & 0 & 1 & 1 & 1 & 0 & 1 & 0 \\
\hline & 32 & 32 & 15 & 17 & 20 & 12 & 31 & 1 & 8 & 24 \\
\hline & & & \multicolumn{2}{|c|}{32} & & & & & & \\
\hline
\end{tabular}

Table 5: Background information on the parents in School D, the importance they attach to science and their stated influence on their children's choice of subjects.

Respondents' science education.

Out of 32 parents, 20 had studied science at secondary level, whilst 12 do not have a science background.

The importance of studying science. An overwhelming number of parents (31 out of 32) in school D attach great importance to the study of science. They stated that science is interesting and vital as it enables them to know what is happening around them and to their body. They 
appreciate that many jobs require knowledge of science subjects. In response to the question: Do you think the study of science is important?, the excerpts given below indicate their views.

Parent D1, who is male, of Hindu origin, does manual work and has not studied science as he has only studied up to primary level, replied:

Science is important. Because nowadays everywhere we use science.

Parent D2, who is female of Hindu origin, does manual work and has not studied science, said:

So as to know what is happening in the world. So as we know what is happening to ourselves.

In response to the question: Would you like your daughter/son to study science after Form III? Give reasons for your answer, the parents' views indicated that science offered good possibilities for jobs:

Parent D1: Yes. If my daughter after her education wants to search for a job, I think if she has a science certificate she can find it easily.

Parent D2: Yes, because my daughter is very good in science. Because my daughter loves doing science so as one day she can become a professional scientist.

In response to the question: What would you like your daughter/son to do as a career?, parents D1 and D2 said they left the choice of the career to their daughters: 
Parent D1: Depends on my daughter. Because I can't make her choice. Everyone has the right to choose everything at every time as it concerns her education.

Parent D2: Because she is doing something brave and great.

The parents' statements tend to show that they believed that their daughters had the right to decide on their choice of career.

Parents' influence on choice of subjects. The parents on the whole claimed that they do not exert any influence on the choice of subjects. In response to the question: Do you influence your daughter/son in the choice of subjects? If yes, how? If no, who influences her/him?, parents D1 and D2 had contrasting opinions on this issue. The following statements indicate their views:

Parent D1: No one because she will take part in the exams, not us.

Parent D2: Yes. By encouraging her to take this subject and my daughter knows why she is choosing her subject.

The parents in school D are predominantly manual workers and yet they would like their children to aim high so as to improve their status in life and choose a career that suits them. The views expressed by the majority of the parents in school $D$ suggest that they let their sons or daughters decide on the choice of subjects. Parent D2 represents the minority of parents who claim to influence their daughters to choose their subjects by encouraging them to study science and guide them in the choice of career.

\section{Discussion and Conclusion}

The parents' questionnaire aimed at finding out if parents felt they had any influence on their children's choice of subjects at the point of choice, which is at Form III level. The pattern of results from the questionnaire data shows that the majority of the parents, irrespective of their social background, claim that they do not influence their children in choosing their 
subjects at that level. The data also indicate that parents do not make any distinction regarding the importance of science to either boys or girls. There are some cases, for example in school B, where having a relative as a role model in the family is a predictor of whether a girl chooses science (cf. Gorgolina \& Swartz, 1992; Jacobs, 2005). Some parents claimed that they influenced their children in respect to the question of choice of subjects and this is probably due to the concerns they have regarding the aspirations of their children and job prospects in the field of science. For example, one parent who said that she influenced her daughter on her choice of subject stated that she encouraged her daughter in the subjects that she (the daughter) liked and in which she performed well. Others stated that while they left the choice to the children themselves, they expected them to have some guidance from teachers' role modelling on this issue of choice (cf. Kellner et al., 2010).

Parents provide their children with cultural capital by transmitting the skills, values and knowledge needed to succeed in the current education system (Bourdieu \& Passeron, 1990). Schools A and C are single-sex girls' schools and schools B and D are mixed-sex; it is both noteworthy and encouraging that the parents state that they give equal importance to the study of science irrespective of the gender of their children (cf. Koballa, 1990; Andre et al., 1999). Though the choice of subjects and eventual career trajectory are critical moments in the educational development of their children, parents in this study on the whole tend to leave the choice to their children. Overall, 87 out of 112 parents maintained that they do not influence their children in choosing their subjects.

Peer and teacher influence can be both an asset and a liability if proper choice is not made at that crucial moment. The intrinsic attraction and the perceived relevance of the topics within school science appear to be influential in the choice of subjects and career path. Adolescence is a crucial period in the life of young people and one wonders whether a right choice is made at that time if proper guidance is not provided. Parents who state that they do not influence their children justify their stance by convincing themselves that their children are capable of making the right choice because they are more aware of their potential. Parents are perhaps conscious of the fact that adolescent girls are creating or developing their own identities and that their self-perception could possibly influence their choice of academic subjects (Solomon, 2003). Furthermore, teacher role modelling and women scientists could be having an effect on the interest of girls in academic subjects and influencing their choices (Bleeker \& Jacobs, 2004). Breakwell and Beardsell (1992) suggest that peers may be influential in the choice of subjects to a certain extent but point out that it is not a dominant factor. 
The results for these four Mauritian schools suggest that parental influence on the choice of subjects, at least in the parents' view, is not a strong factor in the choice of science subjects. Furthermore, there does not seem to be any difference in the results obtained from the four different schools. Other studies have shown that girls generally tend to pay more attention than do boys to the advice of their parents where choice of subjects and career are concerned (Dawson \& O'Connor, 1991). Additionally, perceived supports from parents, teachers and adults that girls trust have been found to be important reason for girls' choice of science subjects (Kelly, 1988; Archer et al., 2014). The findings from this study indicate that the majority of parents maintain that they leave the choice of subjects and careers to their daughters with the belief that they may be sufficiently guided by the schools and confident of their daughters' self-esteem and capabilities in the subjects of their choice.

\section{References}

Andre T., Whigham M., Hendrickson A., \& Chambers S. (1999). Competency beliefs, positive effect and gender stereotypes of elementary students and their parents about science versus other school subjects, Journal of Research in Science Teaching, 36, 719-747.

Archer, L., DeWitt, J., Osborne, J., Dillon, J., Willis, B., \& Wong, B. (2010). “Doing” science versus "being" a scientist: Examining 10/11-year-old schoolchildren's constructions of science through the lens of identity. Science Education, 94, 617-639.

Archer, L., DeWitt, J., Osborne, J., Dillon, J. Willis, B., \& Wong, B. (2012). Science aspirations, capital, and family habitus: How families shape children's engagement and identification with science. American Educational Research Journal, 49, 881-908.

Archer, L., DeWitt, J., Osborne, J., Dillon, J., Willis, B., \& Wong, B. (2013). Not Girly, not sexy, not glamorous: Primary school girls' and parents' constructions of science aspirations. Pedagogy, Culture \& Society, 21(1), 171-194.

Archer, L., DeWitt, J., Osborne, J., Dillon, J., Willis, B., \& Wong, B. (2014). ASPIRES. Young people's science and career aspirations, age 10-14. King's College London: Department of Education \& Professional Studies.

Atkins (2013). Britain's got talented female engineers. Successful women in engineering: a careers research study. Atkins Limited, www.atkinsglobal.com.

Bandura, A. (1977). Social Learning Theory. Englewood Cliffs, NJ: Prentice-Hall.

Baram-Tsabari, A., Sethi, R., Bry, L., \& Yarden, A. (2009). Identifying students' interests in biology using a decade of self-generated questions. Eurasian Journal of Mathematics, Science and Technology Education, 61(1), 63-75. 
Baranowski T., Cullen K. W., \& Nicklas T. (2002). School-based obesity prevention: a blueprint for taming the epidemic. American Journal of Health Behaviour, 26, 486-493.

Bengtsson, M. (1983). Foraldraidentifikation hosksinnliga naturvetareoch humanisterutsecklingspsyhologiskad, ifferentiella och socialpsyhologisaksapekter [Parental identification on the part of women studying natural sciences or the arts - Developmental, differential and social psychological aspects]. Doctoral thesis in Swedish with an English summary, Lund University: Department of Applied Psychology.

Biggart, A., Deacon, K., Dobbie, F., Furlong, A., Given, L., \& Hinds, K. (2004). Findings from the Scottish School Leavers Survey: 17 in 2003. Edinburgh: Scottish Executive, available at: www.scotland.gov.uk/library5/education/17in03.pdf.

Bourdieu, P., \& Passeron, J. (1990). Reproduction in Education, Society and Culture (Theory, Culture and Society). London: Sage.

Breakwell, G. M., \& Beardsell, S. (1992). Gender, parental and peer influences on science attitudes and activities, Public Understanding of Science, 1, 183-197.

Bybee, R. (1997). Achieving Scientific Literacy: From Purposes to Practices. Portsmouth, NH: Heinemann.

Dawson, C., \& O'Connor, P. (1991). Gender differences when choosing school subjects: parental push and career pull: some tentative hypotheses. Research in Science Education, 21, 55-64.

Digest of Education Statistics, (2013), Ministry of Finance and Economic Development, Mauritius.

Dryler, H. (1998). Parental role models, gender and educational choice. British Journal of Sociology, 49, 375-398.

Christensen, R., Knezek G., \& Tyler-Wood T. (2014). Student perceptions of Science, Technology, Engineering and Mathematics (STEM) content and careers. Computers in Human Behavior, 34, 173-186.

Epstein, J. L., \& Sanders, M. G. (2002). Family, school, and community partnerships. In M. H. Bornstein (Ed.), Handbook of parenting: Vol. 5. Practical issues in parenting (pp. 407437). Mahwah, NJ: Erlbaum.

Ferreira, J. A., Santos, E. J. R., Fonseca, A. C., \& Haase, R. F. (2006). Early predictors of career development: a ten-year follow-up study. Journal of Vocational Behavior, 70, 61-77.

Fouad, N. A., \& Bynner, J. (2008). Work transitions. American Psychologist, 63, 241-251.

Gogolin, L., \& Swartz, F. (1992). A quantitative and qualitative inquiry into the attitudes toward science and non science college students. Journal of Research in Science Teaching, 29, 487-504. 
Hill, N. E., \& Taylor, L. C. (2004). Parental school involvement and children's academic achievement. Current Directions in Psychological Science, 13, 161-164.

Holland, J. L. (1973). Making Vocational Choices: A theory of careers. Englewood Cliffs, NJ: Prentice-Hall.

Holland, J. L. (1997). Making Vocational Choices: A theory of vocational personalities and work environments (3rd ed.). Odessa, FL: Psychological Assessment Resources.

Jeynes, W. H. (2009). The relationship between parental involvement and urban secondary school student academic achievement: A meta-analysis. Urban Education, 42, 82-110.

Kelly, A. (1988). Option choice for girls and boys. Research in Science and Technological Education, 6, 5-23.

Kellner, D., \& Share, J. (2007). Critical media literacy, democracy, and the reconstruction of education. In D. Macedo \& S.R. Steinberg (Eds.), Media literacy: A reader (p.3-23). New York: Peter Lang Publishing.

Reiss, M., \& Braund, M. (Eds) (2004). Learning Science Outside the Classroom, London: RoutledgeFalmer.

Rose, A. J., \& Smith, R. L. (2008). Sex differences in peer relationships. In Rubin, K. H., Bukowski, W. M., \& Laursen, B. (Eds) Handbook of Peer Interactions, Relationships and Groups, pp. 379-393. New York: Guilford Press.

Salehjee, S., \& Watts, D. M. (2015). Science lives: school choices and 'natural tendencies'. International Journal of Science Education, 37, 727-743.

Seginer, R. (2006). Parents' educational involvement: A developmental ecology perspective. Parenting: Science and Practice, 6, 1-48.

Schreiner C. (2006). Exploring a ROSE- GARDEN Norwegian youth's orientations towards science-seen as signs of late modernities, PhD thesis. Oslo: Faculty of Education, University of Oslo.

Sjoberg, S., \& Schreiner, C. (2010). The ROSE project: An overview of key findings. Available at http://roseproject.no/network/countries/norway/eng/nor-Sjoberg-Schreiner-overview2010.pdf.

Solomon, J. (2003). Home-School Learning of Science: The culture of homes, and pupils' difficult border crossing. Journal of Research in Science Teaching, 40, 219-233.

Stambler, B. J. (1998). An examination of the effects of parental influence on secondary school completion, unpublished EdD dissertation. Albany, NY: State University of New York at Albany.

Wang, M-T., \& Degol J. (2013). Motivational pathways to STEM career choices: Using expectancy-value perspective to understand individual and gender differences in STEM 
fields. Developmental Review, 33(4), 304-340.

Wellcome Trust (2010). Subject Choice in STEM: Factors influencing Young People (aged 14-19) in Education: A Systematic review of UK literature. London: EPPI Centre, Institute of Education, University of London.

Wellington, J. (2000). Teaching and learning secondary science: Contemporary issues and practical opportunities. London: Routledge.

Whiston, S. C., \& Keller, B. K. (2004). The influences of the family of origin on career development: a review and analysis. The Counseling Psychologist, 32(4), 493-568.

\section{APPENDIX 1 \\ PARENTS QUESTIONNAIRE \\ Dear Parents/ Responsible Party}

I am carrying out a survey on science education in Mauritius. I would be very grateful if you could fill in the questionnaire below. I would be very grateful if parents could fill the questionnaire jointly by discussing it together where applicable. Feel free to answer the questions in either English, French or Creole. Please rest assured that all information will be kept confidential and in strict anonymity.

Thanking you,

Jayantee Naugah.

\section{PARENTS' QUESTIONNAIRE}

Please tick in the appropriate column or box.

1. Sex of Respondent : Male

Female

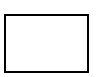

2. Characteristics of Parents

\begin{tabular}{|l|l|l|l|}
\hline & Mother & Father & $\begin{array}{l}\text { Responsible } \\
\text { Party/Guardian }\end{array}$ \\
\hline
\end{tabular}




\begin{tabular}{|l|l|l|l|}
\hline Occupation & & & \\
\hline Education level & & & \\
\hline Graduate & & & \\
\hline HSC & & & \\
\hline SC & & & \\
\hline CPE & & & \\
\hline Other & & & \\
\hline
\end{tabular}

2a. Ethnic group

\begin{tabular}{|l|l|}
\hline Hindu & \\
\hline Muslim & \\
\hline General Population & \\
\hline Chinese & \\
\hline Other & \\
\hline
\end{tabular}

2b.The child attending this school is your:

Daughter $\square$ Son $\square$ Other $\square$ Please specify :

3. No. of children in the family:

Please indicate the age, education level (SC, HSC, Graduate) of your children/wards and their occupation if applicable in the table below) :

\begin{tabular}{|l|l|l|l|}
\hline Children profile & Age/Yrs & Education & Occupation \\
\hline First child & & & \\
\hline Second child & & & \\
\hline Third child & & & \\
\hline & & & \\
\hline & & & \\
\hline
\end{tabular}

4. Did you study science at secondary school? YES NO 
a. If yes, up to what level

\begin{tabular}{|l|l|}
\hline SC & \\
\hline HSC & \\
\hline Degree & \\
\hline Other & \\
\hline
\end{tabular}

b. If no, give reasons for your answer:

5. Do you think the study of science is important?

YES

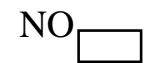

a. Give reasons for your answer.

6. Would you like your daughter/son to study science after Form III? YES

a. Give reasons for your answer.

7. a. What would you like your daughter/son to do as a career?

b.Why?

8. Do you influence your daughter/son in the choice of subjects? YES

$\mathrm{NO}$

8a.If yes, how?

8b. If no, who influences her/ him in choosing the subject? 